\title{
MILK CHEMICAL COMPOSITION OF MERIZE (Capra abegar sp.) AND MILK CONSTITUENTS DISTRIBUTION THROUGH LACTATING SEASON IN MOSUL AREA AND THE EFFECT OF MOTHER AGE ON IT
}

\author{
Khalid H.H. Sharaf \\ Department of Food Science, \\ College Agric\& Forestry, \\ Univer.of Mosul, IRAQ.
}

\author{
Mowaffak Y. Hamdoon \\ Ministry of Higher Education \\ and Sci. research, Baghdad, \\ IRAQ
}

\author{
Adnan I. Abou \\ Technical Institute of Mosul, \\ IRAQ
}

\begin{abstract}
Eighty Hundred individual's morning and evening milk samples were collected from sixteen Iraqi merize goat mothers for five weeks (35 days) milking and lactating period at spring season with climate temperature ranged between $14-23^{\circ} \mathrm{C}$. Milk samples were analyzed for fat, protein, lactose, total solids (TS), and solid nonfat (SNF) percentages, and $\mathrm{pH}$ value. The general average of merize goat's milk composition were $3.91,3.39,4.60,85.52,8.84$, and $12.81 \%$ for fat, protein, lactose, water, SNF, and TS respectively. While the $\mathrm{pH}$ value was 6.73 at milking time. Those milk chemicals constituents were affected by the Merize goat age. Which affect all the milk chemical constituents, while the $\mathrm{pH}$ value was not affected with the goat's age. The fat and lactose of goat's milk distribution along the lactating period were elevated from the first week to the maximal values 4.95 and $4.73 \%$ respectively in the second and third weeks for fat and lactose alternatively, and then declined to the minimum values 3.31 and $4.44 \%$ respectively at the fifth week of lactating period. While the milk water content was adversely proportional to the protein, SNF, and TS percentages. The water percent elevated from the minimum value $83.10 \%$ in the first week to the maximum value $87.25 \%$ in the fifth week, while the protein, SNF and TS were declined from the maximum values $3.78,9.38$, and $14.16 \%$ respectively in the first week to the minimum values $3.25,8.42$, and $11.20 \%$ respectively in the fifth week. The milk $\mathrm{pH}$ distribution value was elevated from 6.71 in the first to the maximum value 6.78 at the third week then declined to the minimum value 6.66 at the fifth week along the studied lactating period.
\end{abstract}

Received: 3/6/2013, Accepted: 11/11/2013.

\section{INTRODUCTION}

Among all foods, milk is the most complete and balanced in nutritional contents (USDA, 1990). In Iraq, goats and merize (small animal body goats) are mostly lived with the sheep cattle's and widely spread in the northern region of Iraq specially the mountain region, and in few numbers in the meddle region. Goat's (including Merize) number reached at 2973000 animals in Iraq (Planning Ministry of Iraq, central statistical division (1976). From that time till now, there is no other information about the number, type, strain, and any studies about the Iraqi goats (unless the Ph.D. studies of Al-Hammdany in Baghdad University, on the Sannen and Al-Shami goats). The merize goat body weight is less than the normal goat mass weight; it is ranged between $12-15 \mathrm{kgs}$. The Iraqi merize goat color is the white, red or brown and in some cases the black. The main purpose for merize production is the thin hair (mohair) production, which is mainly used for cloth, blancked, and carpet manufacturing, in addition, the merize goat used for the meat and milk production (Alkass and Abdul Razzak, 1982). The numbers of various breeds of goats (including 
Merize goat) in the different areas and countries of the world are presented in the following Table (1):

\begin{tabular}{|c|c|c|c|}
\hline Area and country & Million goats & Area and country & Million goats \\
\hline Africa: & 204 & North and Central America: & 13 \\
\hline Sudan & 37 & Mexico & 9 \\
\hline Nigeria & 24 & United states & 1 \\
\hline Ethiopia & 17 & South America: & 25 \\
\hline Asia: & 439 & Brazil & 13 \\
\hline China & 138 & Argentina & 3 \\
\hline Iraq* & 3 & Europe: & 18 \\
\hline India & 121 & Greece & 6 \\
\hline Pakistan & 49 & Spain & 3 \\
\hline Bangladesh & 33 & All the Word: & 700 \\
\hline
\end{tabular}

Source: Anonymous, (1998). * Planning Ministry of Iraq, central statistical division (1976).

There are five major kinds of domesticated goats and Merize goat: 1-The dairy goats. 2-The angora (mohair) goats. 3-The meat goats. 4-The cashmere goats. 5-The pygmy goats (Devendra and MarcaBurns, 1983). Milk produced by dairy goats differs from other domesticated animals milk in that all carotene has been converted into Vit. A in goat milk. The type of curd formed from goat's milk is different from the curd of the other animals milk, because of differences in the major caseins; milk fat in goat's milk is in smaller globules than in other's milk, does not rise or coalesce as readily, and fatty acids. Goat's milk is more readily digested and assimilated by people and animals, because of these differences (Taylor and Field, 2001).

Chemical composition of Merize goat milk: The studies of the chemical composition of goat milk was very few, on the other hand, it was absent for the small body goat breed (merize goat), therefore, this study considered to be the first one in Iraq. Recently the Merize goat milk and meat were economically considered to be a benefit values. Jenness and Sloan (1970) reported that the percentage of goat milk total solid, fat, protein and lactose was $13.2,4.5,2.9$, and $4.1 \%$ respectively. The goat milk fat percent was ranged between $3.1-7.7 \%$. Many researches were concluded that, the chemical composition of the goat milk was affected by the goat breed, seasons of the year, climate temperature, feeding on the concentrate materials or grazing on the plants and branches of trees, as well as the goat milk total solids and fat percent were lower values at summer season, especially when goat grazing on plants. While the goat milk total solids and it fat contents elevated at winter and spring, especially when feeding on the concentrate materials (Alkass and Abdul-Razzak, 1982). The milk chemical composition of Turkey Angora Merize goat were 6.0, 4.4, 4.8 and 15.17\% for fat, protein, Lactose, and TS, respectively (Devendra and MarcaBurns, 1983).

Influence of mother age on the milk chemical composition: The effect of parity and goat age of doe on milk yield are well established. Amble and Jacobi (1959) analyzed 800 lactation records and they found that, milk yields declined from the first to the second lactation, then rose to the fifth, then declined in later lactations. Milk production in the fifth lactation was less than in the first. The data of Mittal et al., (1977) indicated that, milk yields of four years mother age was higher than the yields of younger does. Singh and Acharya (1980) using 3829 lactation records from 1439 Beetal does breed. They found that milk yield was maximum in the third lactation, and 
then declined in the fourth and fifth lactation period. Despite variation in detail, there is a degree of consensus that milk yield reaches a maximum by four or five years old, and does not fall drastically for at least a further three years. Years of age and lactation number do not of course always coincide, particularly breeds which may kid more than once per year, but almost the breeds currently regarded as milk breeds are annual breeders. Few studies showed that, the goat mother age at the delivery time affected the quantity of milk yields, as well as, maximum amount of milk production especially when the goat age reached 15 months, then declined with the continuous aging(Alkass and Abdul-Razzak, 1982). Therefore, the milk yields quantity negatively proportional with the age mother (Alkass and Abdul-Razzak, 1982). In other studies for the Australian goat, Sannen and Toggenburg breeds, the milk production reached the maximum quantity at goat age ranged between 5-7 years (Ronningen, 1964; Alkass and Abdul-Razzak, 1978). The aim of this study firstly was to know the normal milk chemical composition of merize goat lived in Iraq under the tropical Iraqi climate conditions, in normal feeding, and grazing. Secondly was to evaluate the effect of merize mother goat age on its milk chemical constituents.

\section{MATERIALS AND METHODS}

Eight hundred individuals morning and evening of daily milk samples were separately collected from sixteen merize goat mothers (white, black, red, and brown hair breed colors) for five weeks (continuously 35 days) milking and lactating period at spring season (march, 2002) in climate temperature ranged between $14-23^{\circ} \mathrm{C}$ lived in the Nimrod Institute animal farm / Nineveh state. Merize goat mothers aged 2-5 years old and doe body mass ranged between 12-14 kgs, representing all the doe's mothers in this farm at that time. All the animals were apparently healthy. Those goat mothers were daily fed about $2 \%$ of the body weight feeding materials which represented $45 \%$ grazing pasture and $55 \%$ concentrate ration and straw ad labium (Haenlein, 1999). Representative milk individuals separate samples were quantitatively analyzed daily for the fat by using the original Gerber method according to the British Standard Institution, (1951). Total solids (TS.) were determined according to Ling (1963). Solids nonfat (SNF) was calculated by difference between TS and fat. Protein was determined as milk total nitrogen by the semi-microkjeldahl method according to the Anonymous (A.O.A.C., 1980). Lactose percent was determined according to Anonymous (A.O.A.C., 1980) method. In addition, milk pH value estimated by using the (CORNIN Model 10) $\mathrm{pH}$ meter with a glass double electrode.

Statistical analysis: All the data were statistically analyzed for the means character of milk chemical constituents using the variance analysis and standard error for those means using the multiple range tests according to Steel and Torrie (1980) following the computer spss program.

\section{RESULTS AND DISCUSSION}

Table (2) showed the milk chemical composition of merize goat individual mothers for five week lactating period. All the goat milk constituents are significantly $(p<0.05)$ differed with differencing individual mothers and constituents values along the lactation period, These differences were agreed with the conclusion of Mittal (1978); Verma and Chawla (1983), they concluded that, the milk composition of 
individual goat mothers was differed in between, so goat varied and was affected with the various physiological status, environmental conditions and genetic factors in addition to the goat types and strains. Generally, the milk chemical constituents of merize goat mothers was agreed with the results obtained by Al-Jalely et al. (2002). As shown from the milk fat and lactose distribution values, they increased from $40 \%$ respectively in the first week to reach the maximal values $(4.74 \%$ of fat and $4.61 \%$ of lactose) in the second and third lactating period respectively, then declined to reach the minimum values $(3.25 \%$ and $4.50 \%$ respectively) in the fifth week, with a mean values of 3.91 and $4.60 \%$ for fat and lactose respectively, Fig. (1 and 3). While the milk protein, SNF and TS values were negatively proportional to the milk water content, as the water content increased from $82.22 \%$ in the first lactating week to reached the maximum value $87.88 \%$ in the fifth lactating week, the protein, SNF, and TS were declined from $3.75,8.81$ and $13.81 \%$ respectively in the first week to reach the minimum values 3.01, 8.29, and $11.34 \%$ in the fifth week, Fig. (2, 4, 5, and 6), with mean values $3.39,8.73,12.81$, and $85.52 \%$ for milk protein, SNF, TS, and water respectively. There are no significant differences $(\mathrm{p}<0.05)$ between $\mathrm{pH}$ values for merize goat individual mothers, Table (1), but there are differences in milk $\mathrm{pH}$ values along the lactating period. The $\mathrm{pH}$ value increased from 6.71 in the first week to reach the maximum value 6.77 in the third week then declined to the minimum vale 6.67 in the fifth week.

Table (2): Frequently distribution of individual milk chemical composition of Merize goat mother (Mean \pm St.E)*

\begin{tabular}{|c|c|c|c|c|c|c|c|}
\hline \multirow{2}{*}{$\begin{array}{c}\text { Goat } \\
\text { no. }\end{array}$} & \multicolumn{6}{|c|}{$\%$} & \multirow{2}{*}{$\mathrm{pH}$} \\
\hline & fat & protein & lactose & water & SNF. & TS. & \\
\hline 1 & $\begin{array}{c}3.96 \pm 1.57 \\
b\end{array}$ & $\begin{array}{c}3.40 \pm 0.40 \\
b\end{array}$ & $\begin{array}{c}4.50 \pm 0.26 \\
\mathrm{c}\end{array}$ & $\begin{array}{c}82.89 \pm 6.19 \\
\mathrm{~d}\end{array}$ & $\begin{array}{c}9.95 \pm 0.55 \\
a\end{array}$ & $\begin{array}{c}13.91 \pm 3.86 \\
\mathrm{a}\end{array}$ & $6.68 \pm 0.10 \mathrm{a}$ \\
\hline 2 & $\begin{array}{c}4.84 \pm 1.27 \\
\mathrm{a}\end{array}$ & $\begin{array}{c}3.67 \pm 0.32 \\
\mathrm{a}\end{array}$ & $\begin{array}{c}4.69 \pm 0.13 \\
b\end{array}$ & $\begin{array}{c}84.60 \pm 3.86 \\
c\end{array}$ & $\begin{array}{c}8.72 \pm 0.48 \\
\text { c }\end{array}$ & $\begin{array}{c}13.56 \pm 1.53 \\
\mathrm{a}\end{array}$ & $6.76 \pm 0.14 \mathrm{a}$ \\
\hline 3 & $\begin{array}{c}3.55 \pm 1.37 \\
\mathrm{c}\end{array}$ & $\begin{array}{c}3.11 \pm 0.44 \\
\mathrm{c}\end{array}$ & $\begin{array}{c}4.71 \pm 0.22 \\
b\end{array}$ & $\begin{array}{c}87.89 \pm 2.70 \\
a\end{array}$ & $\begin{array}{c}7.90 \pm 0.50 \\
\mathrm{~d}\end{array}$ & $\begin{array}{c}11.44 \pm 1.86 \\
\mathrm{~d}\end{array}$ & $6.68 \pm 0.07 \mathrm{a}$ \\
\hline 4 & $\begin{array}{c}4.70 \pm 1.97 \\
\mathrm{a}\end{array}$ & $\begin{array}{c}3.47 \pm 0.42 \\
b\end{array}$ & $\begin{array}{c}4.80 \pm 0.14 \\
\mathrm{a}\end{array}$ & $\begin{array}{c}85.94 \pm 2.56 \\
b\end{array}$ & $\begin{array}{c}8.38 \pm 0.48 \\
\mathrm{c}\end{array}$ & $\begin{array}{c}13.08 \pm 2.14 \\
\mathrm{~b}\end{array}$ & $6.77 \pm 0.06 \mathrm{a}$ \\
\hline 5 & $\begin{array}{c}3.65 \pm 1.84 \\
\mathrm{c}\end{array}$ & $\begin{array}{c}3.75 \pm 0.61 \\
a\end{array}$ & $\begin{array}{c}4.90 \pm 0.20 \\
\mathrm{a}\end{array}$ & $\begin{array}{c}85.64 \pm 2.48 \\
b\end{array}$ & $\begin{array}{c}9.47 \pm 0.39 \\
b\end{array}$ & $\begin{array}{c}13.12 \pm 1.91 \\
b\end{array}$ & $6.78 \pm 1.91 \mathrm{a}$ \\
\hline 6 & $\begin{array}{c}3.35 \pm 1.55 \\
\mathrm{~d}\end{array}$ & $\begin{array}{c}3.53 \pm 0.40 \\
b\end{array}$ & $\begin{array}{c}4.60 \pm 0.22 \\
b\end{array}$ & $\begin{array}{c}86.40 \pm 1.45 \\
\mathrm{a}\end{array}$ & $\begin{array}{c}8.97 \pm 0.54 \\
\mathrm{c}\end{array}$ & $\begin{array}{c}12.32 \pm 1.76 \\
\mathrm{c}\end{array}$ & $6.75 \pm 0.17 \mathrm{a}$ \\
\hline 7 & $\begin{array}{c}3.76 \pm 1.57 \\
b\end{array}$ & $\begin{array}{c}3.20 \pm 0.40 \\
b\end{array}$ & $\begin{array}{c}4.30 \pm 0.26 \\
\mathrm{c}\end{array}$ & $\begin{array}{c}82.87 \pm 6.19 \\
\mathrm{~d}\end{array}$ & $\begin{array}{c}9.95 \pm 0.55 \\
a\end{array}$ & $\begin{array}{c}13.71 \pm 3.86 \\
\mathrm{a}\end{array}$ & $6.66 \pm 0.10 \mathrm{a}$ \\
\hline 8 & $\begin{array}{c}4.64 \pm 1.27 \\
\mathrm{a}\end{array}$ & $\begin{array}{c}3.47 \pm 0.32 \\
\mathrm{a}\end{array}$ & $\begin{array}{c}4.49 \pm 0.13 \\
b\end{array}$ & $\begin{array}{c}84.49 \pm 3.86 \\
\mathrm{c}\end{array}$ & $\begin{array}{c}8.72 \pm 0.48 \\
c\end{array}$ & $\begin{array}{c}13.36 \pm 1.53 \\
\mathrm{a}\end{array}$ & $6.74 \pm 0.14 \mathrm{a}$ \\
\hline 9 & $\begin{array}{c}3.35 \pm 1.37 \\
\mathrm{c}\end{array}$ & $\begin{array}{c}2.99 \pm 0.44 \\
\mathrm{c}\end{array}$ & $\begin{array}{c}4.51 \pm 0.22 \\
b\end{array}$ & $\begin{array}{c}87.87 \pm 2.70 \\
\mathrm{a}\end{array}$ & $\begin{array}{c}7.88 \pm 0.50 \\
\mathrm{~d}\end{array}$ & $\begin{array}{c}11.24 \pm 1.86 \\
\mathrm{~d}\end{array}$ & $6.66 \pm 0.07 \mathrm{a}$ \\
\hline 10 & $\begin{array}{c}4.50 \pm 1.97 \\
\mathrm{a}\end{array}$ & $\begin{array}{c}3.27 \pm 0.42 \\
b\end{array}$ & $\begin{array}{c}4.60 \pm 0.14 \\
\mathrm{a}\end{array}$ & $\begin{array}{c}85.92 \pm 2.56 \\
b\end{array}$ & $\begin{array}{c}8.39 \pm 0.48 \\
\mathrm{c}\end{array}$ & $\begin{array}{c}12.88 \pm 2.14 \\
b\end{array}$ & $6.75 \pm 0.06 \mathrm{a}$ \\
\hline 11 & $\begin{array}{c}3.45 \pm 1.84 \\
\mathrm{c}\end{array}$ & $\begin{array}{c}3.55 \pm 0.61 \\
\mathrm{a}\end{array}$ & $\begin{array}{c}4.70 \pm 0.20 \\
\mathrm{a}\end{array}$ & $\begin{array}{c}85.53 \pm 2.48 \\
b\end{array}$ & $\begin{array}{c}9.47 \pm 0.39 \\
b\end{array}$ & $\begin{array}{c}12.92 \pm 1.91 \\
b\end{array}$ & $6.76 \pm 1.91 \mathrm{a}$ \\
\hline 12 & $\begin{array}{c}3.15 \pm 1.55 \\
\mathrm{~d}\end{array}$ & $\begin{array}{c}3.33 \pm 0.40 \\
\text { b }\end{array}$ & $\begin{array}{c}4.40 \pm 0.22 \\
b\end{array}$ & $\begin{array}{c}86.38 \pm 1.45 \\
\text { a }\end{array}$ & $\begin{array}{c}8.97 \pm 0.54 \\
\text { b }\end{array}$ & $\begin{array}{c}12.12 \pm 1.76 \\
\mathrm{c}\end{array}$ & $6.73 \pm 0.17 \mathrm{a}$ \\
\hline
\end{tabular}




\begin{tabular}{|c|c|c|c|c|c|c|c|}
\hline 13 & $\begin{array}{c}3.35 \pm 1.37 \\
\mathrm{c}\end{array}$ & $\begin{array}{c}2.99 \pm 0.44 \\
\mathrm{c}\end{array}$ & $\begin{array}{c}4.51 \pm 0.22 \\
\mathrm{~b}\end{array}$ & $\begin{array}{c}87.87 \pm 2.70 \\
\mathrm{a}\end{array}$ & $\begin{array}{c}7.89 \pm 0.50 \\
\mathrm{~d}\end{array}$ & $\begin{array}{c}11.24 \pm 1.86 \\
\mathrm{~d}\end{array}$ & $6.66 \pm 0.07 \mathrm{a}$ \\
\hline 14 & $\begin{array}{c}4.50 \pm 1.97 \\
\mathrm{a}\end{array}$ & $\begin{array}{c}3.27 \pm 0.42 \\
\mathrm{~b}\end{array}$ & $\begin{array}{c}4.60 \pm 0.14 \\
\mathrm{a}\end{array}$ & $\begin{array}{c}85.92 \pm 2.56 \\
\mathrm{~b}\end{array}$ & $\begin{array}{c}8.37 \pm 0.48 \\
\mathrm{c}\end{array}$ & $\begin{array}{c}12.88 \pm 2.14 \\
\mathrm{~b}\end{array}$ & $6.75 \pm 0.06 \mathrm{a}$ \\
\hline 15 & $\begin{array}{c}3.65 \pm 1.84 \\
\mathrm{c}\end{array}$ & $\begin{array}{c}3.75 \pm 0.61 \\
\mathrm{a}\end{array}$ & $\begin{array}{c}4.90 \pm 0.20 \\
\mathrm{a}\end{array}$ & $\begin{array}{c}85.55 \pm 2.48 \\
\mathrm{~b}\end{array}$ & $\begin{array}{c}9.47 \pm 0.39 \\
\mathrm{~b}\end{array}$ & $\begin{array}{c}13.12 \pm 1.91 \\
\mathrm{~b}\end{array}$ & $6.78 \pm 1.91 \mathrm{a}$ \\
\hline 16 & $\begin{array}{c}3.35 \pm 1.55 \\
\mathrm{~d}\end{array}$ & $\begin{array}{c}3.53 \pm 0.40 \\
\mathrm{~b}\end{array}$ & $\begin{array}{c}4.60 \pm 0.22 \\
\mathrm{~b}\end{array}$ & $\begin{array}{c}86.40 \pm 1.45 \\
\mathrm{a}\end{array}$ & $\begin{array}{c}8.97 \pm 0.54 \\
\mathrm{c}\end{array}$ & $\begin{array}{c}12.32 \pm 1.76 \\
\mathrm{c}\end{array}$ & $6.75 \pm 0.17 \mathrm{a}$ \\
\hline $\begin{array}{c}\mathrm{G} . \\
\text { mean }\end{array}$ & $3.91 \pm 1.29$ & $3.39 \pm 0.43$ & $4.60 \pm 0.19$ & $85.52 \pm 3.21$ & $8.84 \pm 0.49$ & $12.81 \pm 2.18$ & $6.73 \pm 0.41$ \\
\hline
\end{tabular}

Merize: Iraqi mountain small goats. St.E: Standard error. SNF: Solid nonfat. TS: Total solids. G.mean; General mean. *General mean of sixteen goat mothers used for analysis.

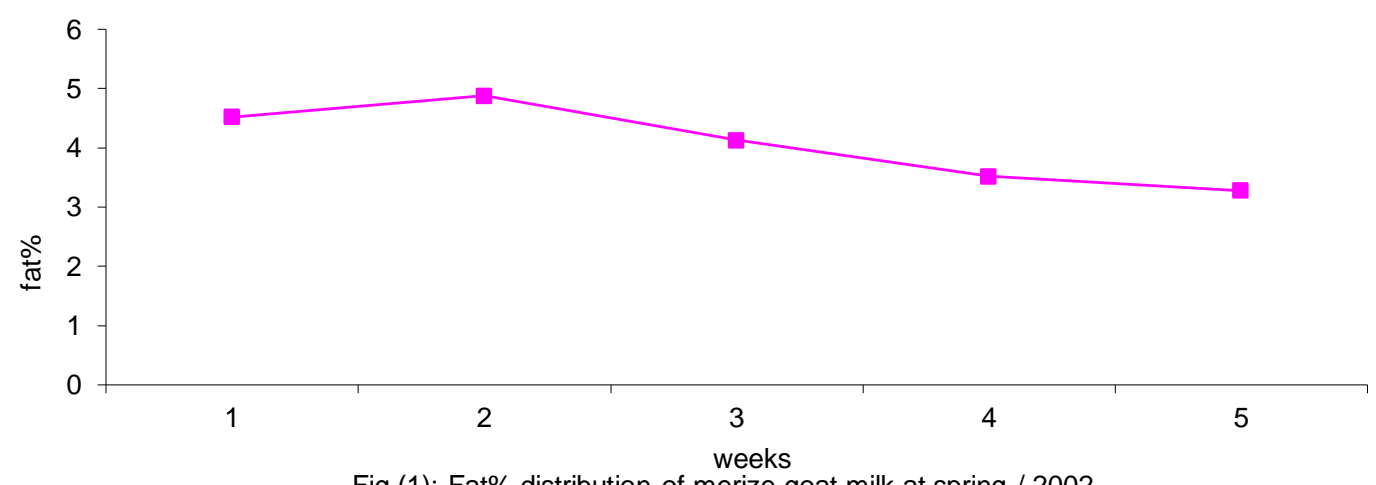

Fig.(1): Fat\% distribution of merize goat milk at spring / 2002

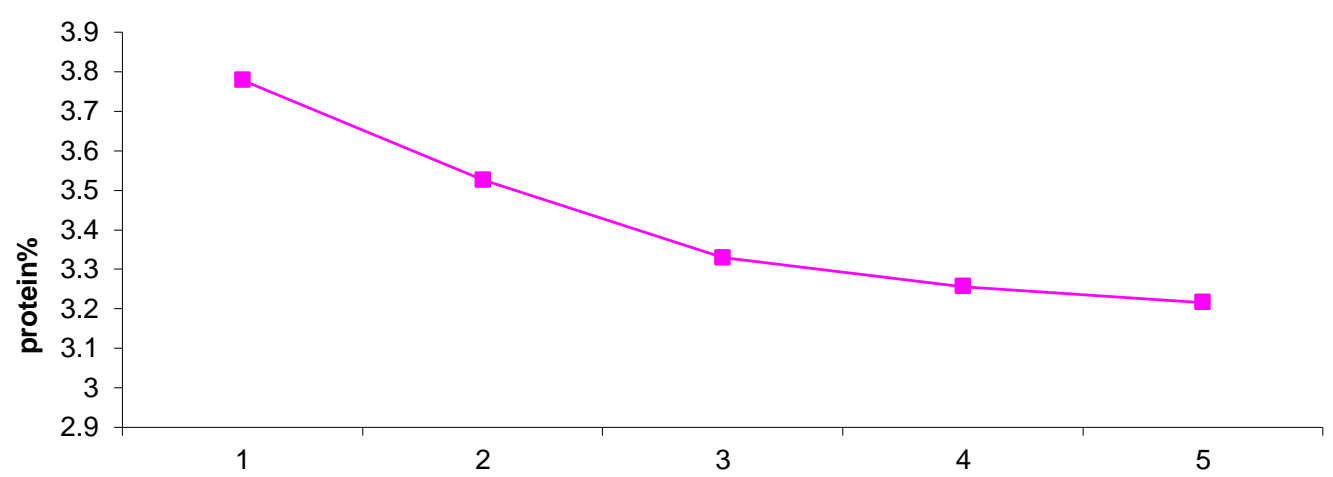

Fig.(2): Protein\% distribution of merize goat milk at spring / 2002

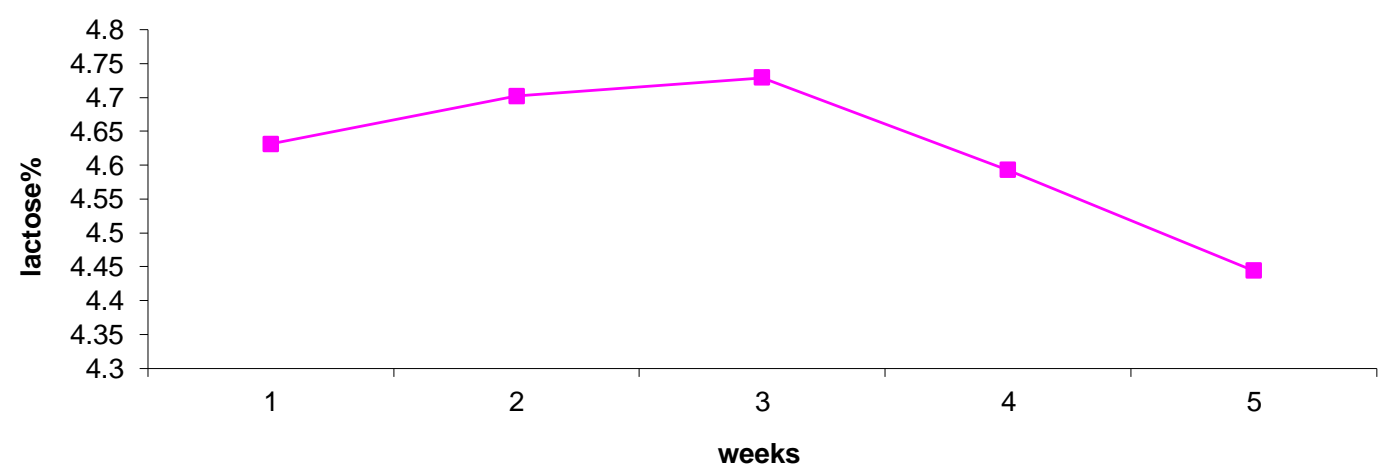

Fig.(3): Lactose\% distribution of merize goat milk at spring / 2002 
Mesopotamia J. of Agric.

ISSN: 2224 - 9796 (Online)

مجلــــة زر اعـــة الــر افديـنـ

Vol. (45) No. (4) 2017

ISSN: 1815 - 316 X (Print)

المجلد (45) العدد (4) 2017

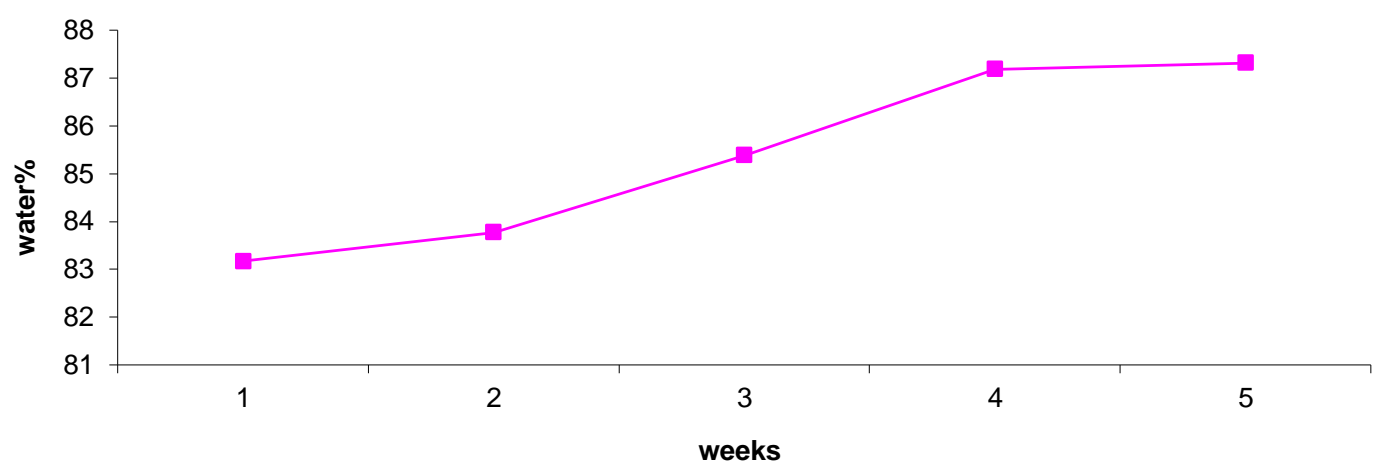

Fig.(4): Water\% distribution of merize goat milk at spring / 2002

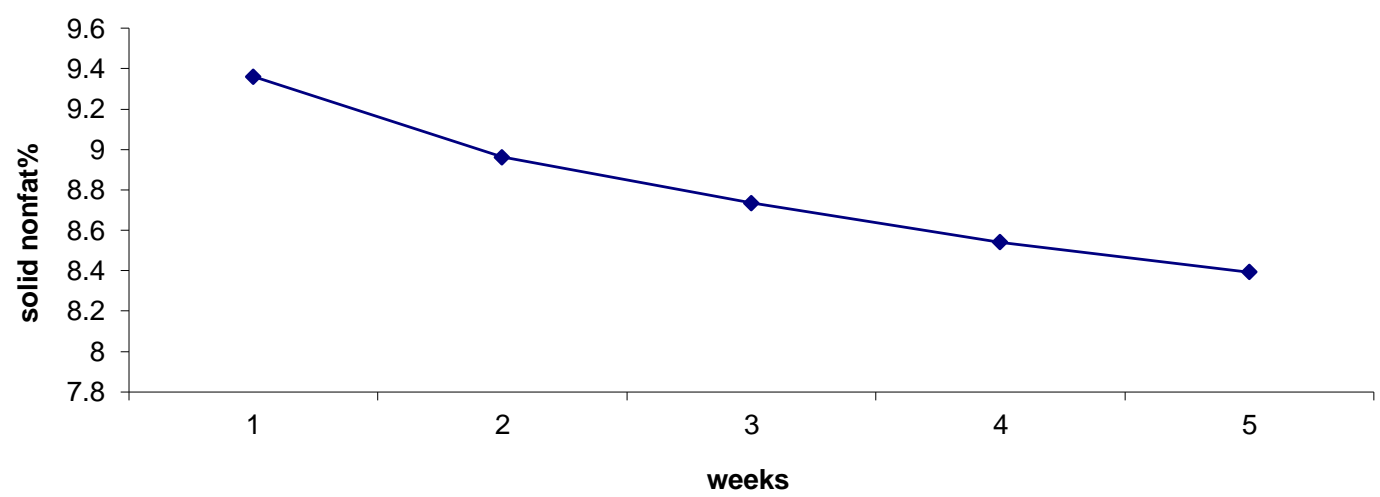

Fig.(5): Solid nonfat\% distribution of merize goat milk at spring / 2002

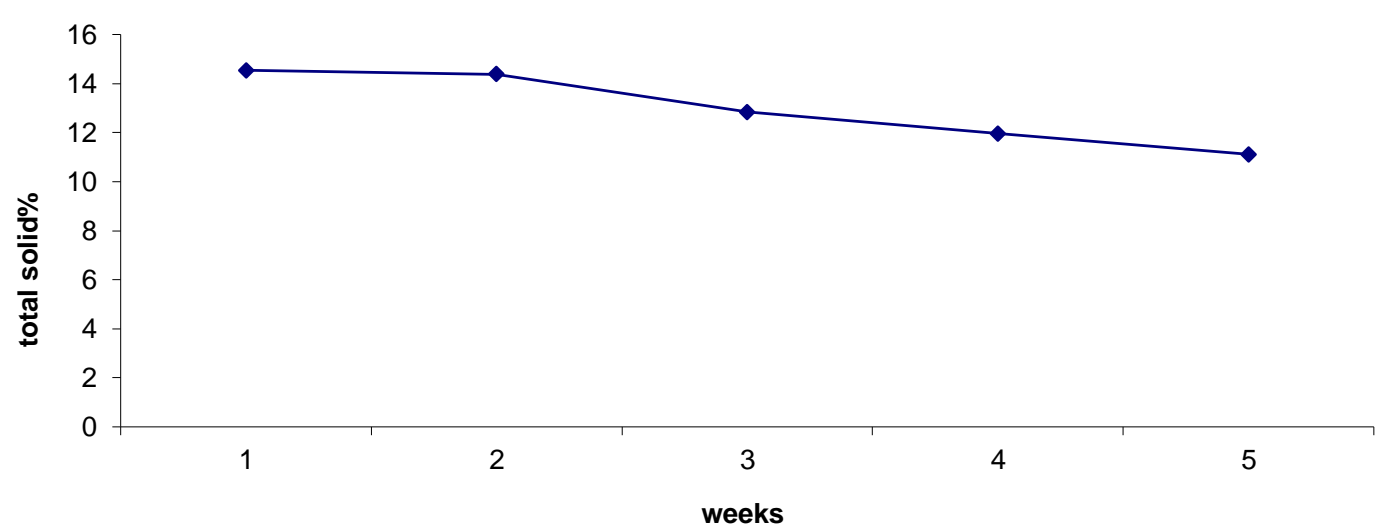

Fig.(6): Total solid\% distribution of merize goat milk at spring / 2002 


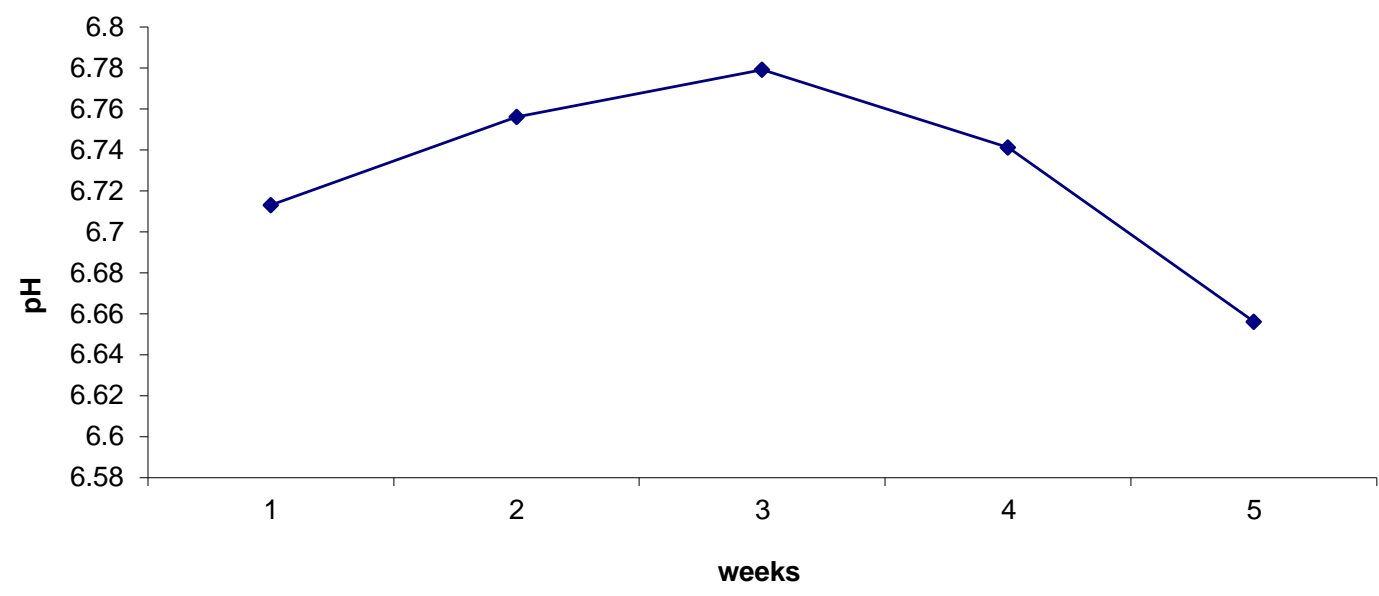

Fig.(7): pH distribution of merize goat milk at spring / 2002

Table (3) showed, the effect of goat mother age on the milk chemical constituents, as seen there are significant differences $(p<0.05)$ in milk composition (fat, protein, lactose, SNF, TS), in addition, to the milk water content between the merize goat individuals mothers. These results were agreed with the results obtained by Al-Jalely et al. (2002). While there are no significant difference in $\mathrm{pH}$ values. Milk fat, protein, lactose, SNF, TS were increased to the maximum values at the second year of merize goat mother age. Those milk constituents were indirectly proportional to the goat age, as the age increased from 2 to reached 5 years old, the milk chemical constituents decreased, Table (3).

Table (3): Age effect of merize goat mother on the chemical composition and $\mathrm{pH}$ of milk, (Mean \pm St.E)*

\begin{tabular}{|c|c|c|c|c|c|c|c|}
\hline \multirow{2}{*}{$\begin{array}{c}\text { goat } \\
\text { Age } \\
\text { (year) }\end{array}$} & fat & protein & lactose & water & SNF. & TS. & pH \\
\cline { 2 - 7 } & $\begin{array}{c}5.01 \pm 2.79 \\
\mathrm{a}\end{array}$ & $\begin{array}{c}3.62 \pm 0.26 \\
\mathrm{a}\end{array}$ & $\begin{array}{c}4.74 \pm 0.12 \\
\mathrm{a}\end{array}$ & $\begin{array}{c}84.42 \pm 3.76 \\
\mathrm{c}\end{array}$ & $\begin{array}{c}9.24 \pm 0.36 \\
\mathrm{a}\end{array}$ & $\begin{array}{c}13.92 \pm 2.44 \\
\mathrm{a}\end{array}$ & $6.76 \pm 0.12 \mathrm{a}$ \\
\hline 2 & $\begin{array}{c}4.57 \pm 1.88 \\
\mathrm{~b}\end{array}$ & $\begin{array}{c}3.31 \pm 0.46 \\
\mathrm{c}\end{array}$ & $\begin{array}{c}4.66 \pm 0.20 \\
\mathrm{~b}\end{array}$ & $\begin{array}{c}86.37 \pm 2.83 \\
\mathrm{a}\end{array}$ & $\begin{array}{c}8.63 \pm 0.54 \\
\mathrm{c}\end{array}$ & $\begin{array}{c}12.59 \pm 2.41 \\
\mathrm{c}\end{array}$ & $6.74 \pm 0.09 \mathrm{a}$ \\
\hline 3 & $\begin{array}{c}3.40 \pm 1.66 \\
\mathrm{~d}\end{array}$ & $\begin{array}{c}3.54 \pm 0.52 \\
\mathrm{~b}\end{array}$ & $\begin{array}{c}4.65 \pm 0.26 \\
\mathrm{~b}\end{array}$ & $\begin{array}{c}85.97 \pm 2.02 \\
\mathrm{~b}\end{array}$ & $\begin{array}{c}9.02 \pm 0.66 \\
\mathrm{~b}\end{array}$ & $\begin{array}{c}12.62 \pm 1.83 \\
\mathrm{c}\end{array}$ & $6.75 \pm 0.14 \mathrm{a}$ \\
\hline 4 & $\begin{array}{c}4.01 \pm 1.49 \\
\mathrm{c}\end{array}$ & $\begin{array}{c}3.31 \pm 0.43 \\
\mathrm{c}\end{array}$ & $\begin{array}{c}4.54 \pm 0.22 \\
\mathrm{c}\end{array}$ & $\begin{array}{c}84.89 \pm 4.78 \\
\mathrm{c}\end{array}$ & $\begin{array}{c}8.56 \pm 0.53 \\
\mathrm{c}\end{array}$ & $\begin{array}{c}13.02 \pm 2.70 \\
\mathrm{~b}\end{array}$ & $6.70 \pm 0.11 \mathrm{a}$ \\
\hline $\begin{array}{c}\text { G. } \\
\text { mean }\end{array}$ & $4.07 \pm 1.87$ & $3.42 \pm 0.45$ & $4.62 \pm 0.22$ & $85.36 \pm 3.73$ & $8.80 \pm 0.60$ & $12.97 \pm 2.39$ & $6.73 \pm 0.12$ \\
\hline
\end{tabular}

SNF: Solid nonfat. TS: Total solids. G.mean: General mean. * Mean for five goat mothers used in the analysis.

Table (4): The multiple comparisons between the weekly milking, goat no. and certain significant milk constituents (Post Hoc Tests).

\begin{tabular}{|c|c|c|c|c|c|}
\hline \multirow{2}{*}{$\begin{array}{c}\text { Independent var. } \\
\text { (Chemical composition) }\end{array}$} & \multicolumn{2}{|c|}{$\begin{array}{c}\text { Dependent var. } \\
\text { Lactating period } \\
\text { (in week) }\end{array}$} & $\begin{array}{c}\text { Goat age } \\
\text { (year) }\end{array}$ & \multirow{2}{*}{ LSD } & \multirow{2}{*}{ Sig. } \\
\hline Fat & 2 & 5 & $1.6050^{*}$ & 0.6880 & 0.023 \\
\hline
\end{tabular}




\begin{tabular}{|c|c|c|c|c|c|}
\hline & 1 & 3 & $0.4490^{*}$ & 0.1570 & 0.006 \\
\hline & 1 & 4 & $0.5220^{*}$ & 0.1570 & 0.001 \\
\hline & 1 & 5 & $0.5614^{*}$ & 0.1570 & 0.001 \\
\hline Protein & 1 & 5 & $0.1871^{*}$ & 0.0780 & 0.019 \\
\hline & 2 & 5 & $0.2586^{*}$ & 0.0780 & 0.001 \\
\hline & 3 & 5 & $0.2850^{*}$ & 0.0780 & 0.001 \\
\hline Wactose & 4 & 1 & $4.0143^{*}$ & 1.2903 & 0.003 \\
\hline & 4 & 2 & $3.4114^{*}$ & 1.2903 & 0.010 \\
\hline SNF & 5 & 1 & $4.1443^{*}$ & 1.2903 & 0.002 \\
\hline & 5 & 2 & $3.5414^{*}$ & 1.2903 & 0.008 \\
\hline & 1 & 2 & $0.3986^{*}$ & 0.1918 & 0.042 \\
\hline & 1 & 3 & $0.6264^{*}$ & 0.1918 & 0.002 \\
\hline & 1 & 4 & $0.8240^{*}$ & 0.1918 & 0.000 \\
\hline & 1 & 5 & $0.9679^{*}$ & 0.1918 & 0.000 \\
\hline & 2 & 4 & $0.4214^{*}$ & 0.1918 & 0.032 \\
\hline & 2 & 5 & $0.5693^{*}$ & 0.1918 & 0.004 \\
\hline & 1 & 3 & $1.7036^{*}$ & 0.7657 & 0.030 \\
\hline & 1 & 4 & $2.5843^{*}$ & 0.7657 & 0.001 \\
\hline & 5 & 3 & $3.4379^{*}$ & 0.7657 & 0.000 \\
\hline & 2 & 3 & $1.5371^{*}$ & 0.7657 & 0.049 \\
\hline & 2 & 4 & $2.4179^{*}$ & 0.7657 & 0.002 \\
\hline & 2 & 5 & $3.2714^{*}$ & 0.7657 & 0.000 \\
\hline & 3 & 5 & $1.7343^{*}$ & 0.7657 & 0.027 \\
\hline & 2 & 5 & $0.0929^{*}$ & 0.0429 & 0.024 \\
\hline & 3 & 5 & $0.1229^{*}$ & 0.0429 & 0.006 \\
\hline
\end{tabular}

* The mean difference is significant at $\mathrm{p}<0.05$ level.. The significant values are only listed in the table.LSD: Lest significant difference. St.E: Standard error. Sig.: Significant. SNF: Solid nonfat. T.S.: Total solid. Notice: Table contains the significant values of the studied parameters (effect of merize goat age on milk constituents), other values are no significant, therefore not mentioned in Table (4).

Table (4) showed the composition between weekly milking, lactating period (in week); Merize goat individual's effect and the significant milk constituent's values. As seen from the Table that, the fat $\%$ increased to the maximum value at the second week lactating period for merize goat mother aged 5 years. The milk protein $\%$ be at the maximum value from the first week of lactating and so on in continuous level during this lactating period for goat mother aged 3, 4, and 5 years old. Those results were not agreed for milk protein only with the results obtained by A-Jalely et al. (2002). The lactose $\%$ is at the maximum value from the first week of lactating and so elevated in values for the second and third week of lactating period for goat mothers aged 5 years old. While the milk water content increased in the fourth and fifth week lactating period for goat mothers more than one and 2 years old. The milk SNF, TS, and $\mathrm{pH}$ values were different with the lactating week different period, and varied with the goat mother age. 
التركيب الكيميائي لحليب الماعز الجبلي (المرعز) .Capra abegar sp وتوزيع مكوناته خلال موسم الحليب في منطقة الموصل وتأثير عمر ألام عليه

$$
\text { المعهد الفني الموصلي، عبو العر اق }
$$

$$
\begin{aligned}
& \text { موفق يحيى حمدون }
\end{aligned}
$$

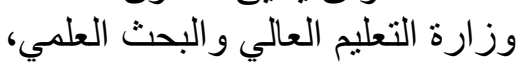

$$
\begin{aligned}
& \text { بغداد-العراق }
\end{aligned}
$$

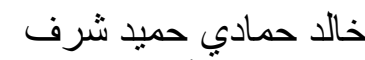
قأسم علوم الأغذية / كلية

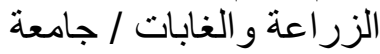

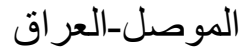

\section{الخلاصة}

جمعت ثمانمائة عينة حليب ممثلة للحلبات الصباحية والمسائية من أمهات المر عز العر اقية و عددها 16

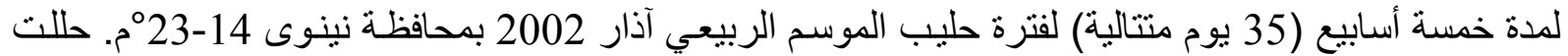

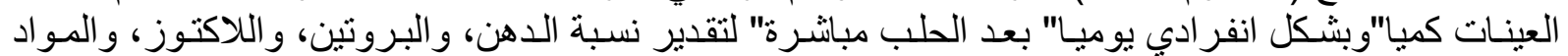

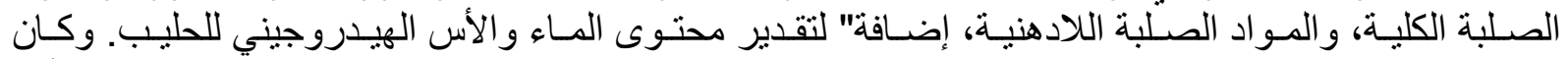

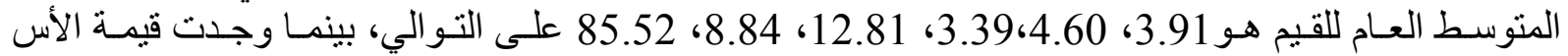

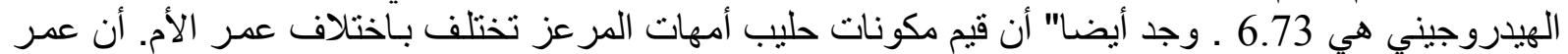

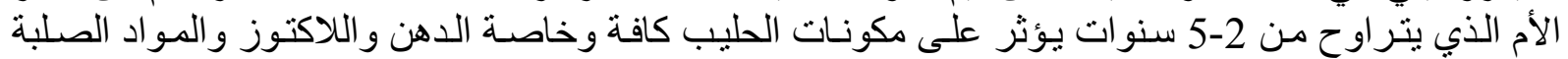
اللادهنية طيلة فترة الحليب. كما وجد أن نوزيع الدهن والدئ اللاكتوز بالحليب يزداد منذ بداية فترة الحليب حتى يصل

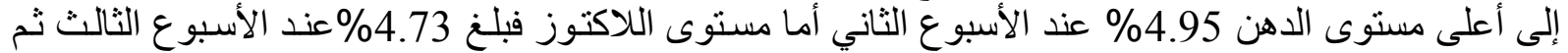
ينخفض المكونان إلى أدنى مسنتوى لهما

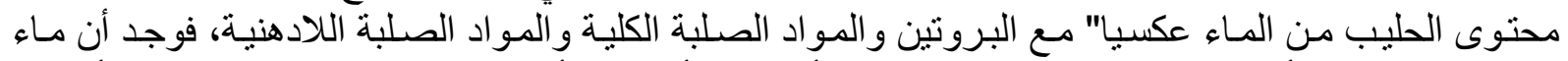

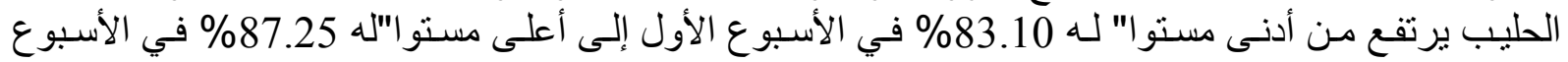

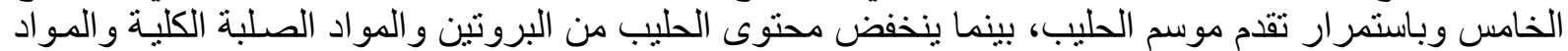

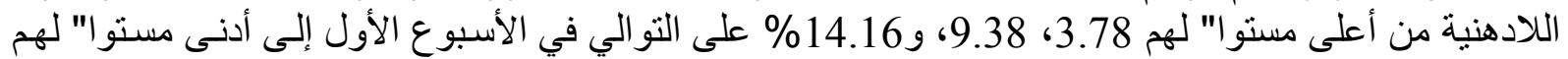

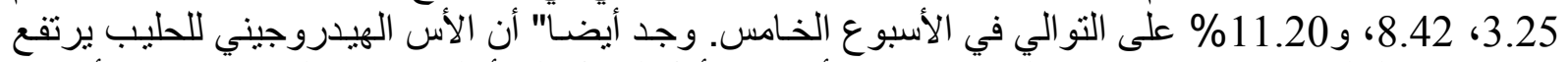

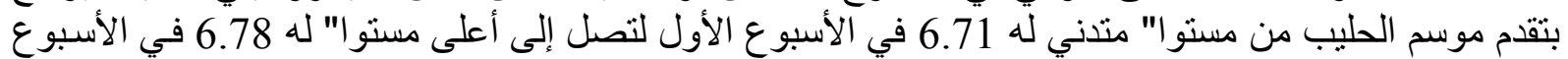
الثالث ثم ينخفض إلى 6.66 في الأسبوع الخامس.

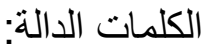

\section{REFERENCES}

Al-Jalely, Z.F., M.K. Asofi, and W.A. Al-Hamdani (2002). Chemical composition of goat milk and its effect of environmental and genetic factors on it. J Al-Kaddisia Veternary |Medicine 1(1): 63-69.

Alkass, J. (1978). Caprine milk: A Study On The Effect Of Stage Of Lactation On Milk Composition Of Sannen And Toggenburg Breed Of Heat Treatment And Rennin Of Milk Proteins. Ph.D. Thesis, University of Reading, U.K.

Alkass, J. and F. Abdul-Razzak, (1982). Goat production. Mosul University Press, Mosul, Iraq. p.16, 40, 50- 51, and 56-58,

Amble, V.N. and T. Jacob (1959). Standards for chemical quality of market milk. Indian Journal Dairy Science, 13: 83-96.

Anonymous, (1951). Gerber method for the determination of fat in milk and milk products. British Standard Institution C.f. Publication No. 696 part 2.

Anonymous, (1980). Official Methods Of Analysis. $13^{\text {th }}$ ed., Assoc. of official analy. Chem., Washington DC. 
Anonymous, (1990). Composition of foods, dairy and egg products. USDA-ARS, Washington DC. Agric. Handbook No. 8.

Anonymous, (1992). Food and Agriculture Organization of the United Nations. Rome, Italy

Devendra, C. and B. Marca-Burns, (1983). Goat Production In The Tropics. Unwin Brothers limited. Commonwealth Agricultural Bureau, London, UK SW1.

Haenlein, G.F.W. (1999). Goat Management: Composition Of Goat Milk and Factors Affecting It. P.1-8.

Jnness, R. and R.E. Sloan (1970). Dairy Science Abstr. 32: 599.

Ling, E.R. (1963). A Text-Book Of Dairy Chemistry. Practical, Vol. 11, $3^{\text {rd }}$ ed. Chapman and Hall Ltd. London. p. 83.

Mittal, J.P. (1978). Relationship among traits of growth and milk production in Jamunapari goats. Indian Journal Dairy Science 32(4): 379-382.

Mittal, J.P.; M.P. Agarwal, and K.S. Bist (1977). Effect of breed, age, season, and para on milk secreting capacity of goats. Indian Veternary Journal 54(6): 449-453.

Planning Ministry of Iraq, central statistical division (1976). Annual Report of Agriculture, Baghdad, Iraq.

Ronningen, K. (1964). Anim. Breed, Abstr. 33, No. 476.

Singh, R.N. and R.M. Acharya (1980). Beetal goat: genetic selection for maximizing lifetime milk production. International Goat and Sheep Research 1(3): 226-233.

Steel, R.G.D. and Torrie, J. H. (1980). Principles and Procedures of Statistics. $2^{\text {nd }}$ ed. New York. McGraw-Hill book Company, Inc.

Taylor, R.E. and T.G. Field (2000). Goat breeding, feeding and management, In: Scientific Farm Animal Production. $7^{\text {th }}$ ed., Prentice Hall, New Jersey, p.644- 660.

Verma, N.K. and Chawla, D.S. (1983). Variation in milk composition in dairy goats. Indian Journal Animal Science 54(6): 539-543. 